\title{
CHANGES OF METHANE CONTENT OF LANDFILL GAS WITH REGARD TO DIFFERENT WIND SPEED INTERVAL
}

\author{
Author(s): \\ T. Molnár - F. Farkas
}

Affiliation:

University of Szeged Faculty of Engineering, Technical Institute

Mars str. 7., 6724, Szeged, Hungary

Email address:

molnart@mk.u-szeged.hu, farkasf@mk.u-szeged.hu

\begin{abstract}
In the recent years in Hungary the continuous increase of solid waste, as a result of private consumption, has become a serious issue. In Hungary currently about 23 million $\mathrm{m} 3$ solid urban waste is formed annually. Sixty-two percent $(62 \%)$ of this waste is household waste and the remaining is waste produced at institutions or service providers which can be treated together with the household waste. Waste management plays a key role in the quality of environment, protecting natural resources and developing environmental security. There can be two basic environmentally harmful effects of waste disposal. The problem of landfill gas from the decomposition of communal waste got into the focus of attention since it was proved that on the Earth the natural and anthropogen methane and the carbo-dioxide emmission contribute to the so-called glass-house effect $[1,2]$
\end{abstract}

\section{Keywords}

landfill gas, methane content, wind speed interval, greenhouse gas.

\section{Introduction}

The quality and quantity of biogas presumably depends on the weather parameters of the refuse dump, the technical parameters of the bio gas recovery system and the organic matter content, typical of the Hódmezővasárhely region. Because of that our objective is to define the the quality and quantity parameters of landfill gas at the refuse dump with regard to the weather parameters, operational factors and the organic matter content. In accordance with the assumption environmental impact can influence directly or indirectly the quality and quantity parameters of the produced landfill gas. Besides the examination of the connection between environmental conditions and gas production it is appropriate to examine the organic matter content of the waste as legal requirements regulate the biodegradable proportion of it. Our objectives are the following under the following headings:

The current relevance and significance of the topic is that by the use of modern, state-of-the-art techniques in accordance with EU standards, we could use alternative forms of energy instead of fossil energy sources for both electric and thermal energy production which has both economic and environmental benefits $[3,4,5,6]$.

\section{Material and methods}

The communal solid waste refuse dump of the „A·S A Hódmezővásárhely Köztisztasági Ltd.” Is located on the outskirts of Hódmezővásárhely on the area No. 01957/1. The refuse dump is situated south of Hódmezővasárhely, west of no. 4414 road, about 5-6 kilometres from the centre. In terms of public service obligation the communal solid waste of Hódmezővásárhely and six other settlements is taken to the refuse dump (Mindszent, Mártély, Földeák, Békéssámson, Nagyér), its area of responsibility is 100.000 people $[7,8,9,10]$.

The elements of landfill gas extracting system are the following: gas wells, gas collecting pipes, gas controller unit, compressor unit, torch, container with gas engine, meteorological station. The collection of landfill gas is with the help of gas wells.

At the beginning there were low drainage gas wells used at the refuse dump but because of their sinking and deformation the effectiveness of gas extraction was impeded. They converted to upper drainage gas wells which are only built after the dump is completely filled or reached a certain height. It does not interfere with the operation and good quality landfill gas is attainable [11, 12, 13].

When preparing the measuring system three measuring points were established (Figure 1.) Measuring point 1 is the two measuring cones, one for measuring the applied depression [mbar] and the other is for measuring the quality compound of the landfill gas (methane [\%], carbon dioxide [\%], oxygen [\%]) and the opening angle of the sluice valve $\left[^{\circ}\right]$. Measuring point 2 is situated at the vacuum pump. Pressure values can be measured in front of and behind the pump, and thus the amount of the pressure difference can be calculated. [8,9]. From the pressure difference flow rate of the extracted landfill gas without pipe friction can be calculated and then, with the pipe diameter, the amount of the produced landfill gas. Measuring point 3 is located at the meteorological station of the refuse dump. It provides the weather parameters: tk: external temperature $\left[{ }^{\circ} \mathrm{C}\right], \varphi$ : air humidity [\%], vsz: windspeed $[\mathrm{m} / \mathrm{s}], \mathrm{h}$ : rainfall intensity $[\mathrm{mm} / \mathrm{day}], \mathrm{Ph}$ : local atmospheric pressure (QFE).

Evaluating data, statistical methods, measuring instruments: for diagnosing the degradation process in the refuse dump and optimizing energy recovery I used a GA2000 type NDIR (Non Dispersive Infra Red) analyzer, working in the medium infrared region.

The data was statistically processed with SPSS for Windows 11.0 program was used. The data was processed by the method 
of analysis of variance. Homogeneity was examined with the Levene-test. When comparing the group-couples Tamhane test (in case of heterogeneity), and LSD test (in case of homogeneity) were applied. The tightness between variables was determined by linear regression analysis. In our examinations we calculated the necessary number of data by using a method by Sváb [14]. In order to be able to determine the necessary number of data in a sample you have to be aware of the standard deviation (s), you have to provide the permissible estimation of errors (h), have to give the $\mathrm{P} \%$ significance level or the likelihood of error.

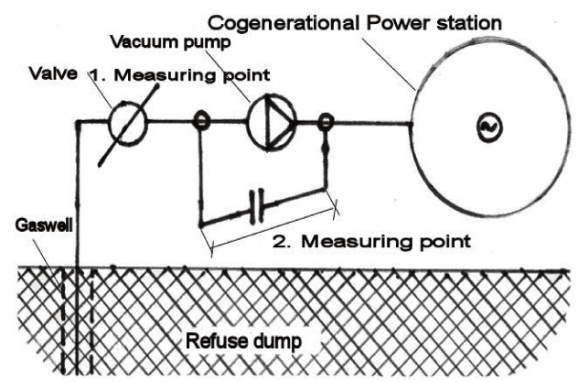

Figure 1 The location of measuring system at the refuse dump $[8,9,10]$

If we know the standard deviation in the unit of measurement of the data and the permissible estimation of errors are given in the same unit of measurement the sample size of the data can be calculated:

$\mathrm{n}$ : number of items, tp\%: critical element of the „t”test, s: standard deviation, h: estimation of errors

$$
n=\frac{t_{P \%}^{2} \cdot s^{2}}{h^{2}}
$$

In case standard deviation is known in percentage (coefficient of variation) and the permissible estimation of errors is also given in percentage then the number of necessary elements can be defined by the following formula:

$\mathrm{n}$ : number of items, tp\%: critical element of the „t”test, s\%: standard deviation percentage (coefficient of variation) (\%), $\mathrm{h} \%$ : estimation of errors percentage (\%)

$$
n=\frac{t_{P \%}^{2} \cdot s \%^{2}}{h \%^{2}}
$$

We made the calculations for a $\mathrm{P}=3 \%$ and $\mathrm{P}=5 \%$ probability level. According to our results in the case of $\mathrm{h} \%=3 \%$ estimation of error the sample size for the statistical analysis of the results and drawing the relevant conclusions is $n=363$ pieces, in the case of $\mathrm{h} \%=5 \%$ estimation of error the necessary sample size is $\mathrm{n}=131$ pieces. On this basis we have concluded that the data we collected $(n=517)$ is sufficient to carry out the appropriate statistical examinations and analysis. Even though we carried out the Levene test, by which we concluded which test to use at the comparison of group pairs (Tamhane or LSD) I found it important to calculate the $\mathrm{CV} \%$ (coefficient of variation) as well. We would like to present the standard deviation within each group by the analysis of coefficient of variation, which was specified by the following formula:

$$
s \%=C V=\frac{s}{\bar{X}} \cdot 100
$$

$\mathrm{CV}$ : coefficient of variation [\%], s: standard deviation, $\mathrm{x}$ : average of dataline
During the examinations we created measuring groups, definition of group establishment is in Table 1 .

Table 1. Definition of group creating and their operating parameters

\begin{tabular}{|c|c|}
\hline $\begin{array}{c}\text { Wind speed } \\
\text { groups }\end{array}$ & $\begin{array}{c}\text { Wind speed } \\
\text { interval } \\
{[\mathrm{m} / \mathrm{s}]}\end{array}$ \\
\hline 1. group & $\mathrm{V}_{\mathrm{sz}}<=0,6$ \\
\hline 2. group & $0,6>\mathrm{v}_{\mathrm{sz}}<=1$ \\
\hline 3. group & $1>\mathrm{v}_{\mathrm{sz}}<=1,3$ \\
\hline 4. group & $1,3>\mathrm{v}_{\mathrm{sz}}<=1,8$ \\
\hline 5. group & $1,8>\mathrm{v}_{\mathrm{Sz}}<=2,4$ \\
\hline 6. group & $\mathrm{v}_{\mathrm{SZ}}>2,4$ \\
\hline
\end{tabular}

During the statistical process we examined what connection can be found between the average temperature interval, relative humidity, barometric pressure, wind speed interval precipitation changes and the quantity and quality parameters of landfill gas in the case of all and each gas well. We found significant differences between group pairs on the basis of the methane content of the pairs. The connection examinations between the variables of the gas wells were made by regression analysis. The results we got through the calculations are presented in charts, graphs and diagrams $[12,17,18,19]$

\section{Results}

During our examination we tried to find relationships between the different wind speed intervals and the methane content values of the landfill gas recovered from the refuse dump. During the construction of a landfill site the heights of the retaining walls can be as high as 15-30 meters. At this height we can assume that the wind conditions might have the effect that despite extraction methane can dissipate from the top layers of the dump. This mostly happens during the loading of the dump when the height of the $3 \mathrm{~m}$ wide and $2 \mathrm{~m}$ high ramparts on the outside edge of the retaining walls gets higher than the height of the waste in the refuse dump. As a result the methane content of the recovered landfill gas can significantly decrease and have higher oxygen content.

The results are in Table 2. where methane content changed between $1-68 \%$. The most favorable value, $51,78 \%$ methane content was measured in the $2^{\text {nd }}$ group in $0,6 \mathrm{~m} / \mathrm{s}>\mathrm{vsz} \leq 1 \mathrm{~m} / \mathrm{s}$ interval, with $\mathrm{n}=99$ sample size. The least favorable value, $47,30 \%$, was found in the 1st group - contrary to what I assumed - in the vsz $\leq 0,6$ wind speed interval and in the 6th group, $49,53 \%$ in the vsz $>2,4 \mathrm{~m} / \mathrm{s}$ wind speed interval. From the results it can be seen that in groups 3,4,5 and 6 changes of wind speed shows small difference in methane content so it is necessary to examine the connection between the volume of gas recovery and prevailing wind speed. Variation of coefficient is $\mathrm{CV} \%=22,81 \%$ in the wind speed interval of the 2 nd group $(0,6>\mathrm{vsz} \leq 1)$. We measured the most favorable methane content value in this case and the minimum and maximum values were between $14-66 \%$ methane content.

Table 2. Results of the relationships between wind speed intervals and methane content

\begin{tabular}{|c|c|c|c|c|c|}
\hline $\begin{array}{c}\text { Wind speed } \\
\text { group }\end{array}$ & $\begin{array}{c}\text { Wind speed } \\
\text { interval } \\
{[\mathrm{m} / \mathrm{s}]}\end{array}$ & $\begin{array}{c}\mathrm{n} \\
{[\mathrm{db}]}\end{array}$ & $\begin{array}{c}\mathrm{CH}_{4} \\
\text { mean } \\
{[\%]}\end{array}$ & $\begin{array}{c}\text { Coefficient } \\
\text { variation } \\
\mathrm{CV} \% \\
{[\%]}\end{array}$ & $\begin{array}{c}\text { Std. } \\
\text { deviation } \\
{[\%]}\end{array}$ \\
\hline 1. group & $\mathrm{V}_{\mathrm{sz}} \leq 0,6$ & 88 & 47,30 & 31,22 & 14,771 \\
\hline 2. group & $0,6>\mathrm{v}_{\mathrm{sz}} \leq 1$ & 99 & 51,87 & 22,81 & 11,832 \\
\hline 3. group & $1>\mathrm{v}_{\mathrm{sz}} \leq 1,3$ & 99 & 49,81 & 30,45 & 15,169 \\
\hline 4. group & $1,3>\mathrm{v}_{\mathrm{sz}} \leq 1,8$ & 99 & 48,65 & 30,58 & 14,880 \\
\hline 5. group & $1,8>\mathrm{v}_{\mathrm{sz}} \leq 2,4$ & 66 & 50,95 & 29,26 & 14,908 \\
\hline 6. group & $\mathrm{V}_{\mathrm{sz}}>2,4$ & 66 & 49,53 & 28,79 & 14,260 \\
\hline & Total & 517 & 49,67 & 28,82 & 14,319 \\
\cline { 2 - 6 }
\end{tabular}


Table 3. Results of wind speed group pairs and methane content differences

\begin{tabular}{|c|c|c|c|c|c|c|c|}
\hline $\begin{array}{c}\text { Wind } \\
\text { speed } \\
\text { group }\end{array}$ & $\begin{array}{c}\text { Wind speed } \\
\text { interval } \\
{[\mathrm{m} / \mathrm{s}]}\end{array}$ & $\begin{array}{c}\mathbf{1 .} \\
\text { group }\end{array}$ & $\begin{array}{c}\mathbf{2 .} \\
\text { group }\end{array}$ & $\begin{array}{c}\mathbf{3 .} \\
\text { group }\end{array}$ & $\begin{array}{c}\mathbf{4 .} \\
\text { group }\end{array}$ & $\begin{array}{c}\mathbf{5 .} \\
\text { group }\end{array}$ & $\begin{array}{c}\mathbf{6 .} \\
\text { group }\end{array}$ \\
\hline 1.group & $\mathrm{v}_{\mathrm{sz}} \leq 0,6$ & - & $*$ & - & - & - & - \\
\hline 2. group & $0,6>\mathrm{v}_{\mathrm{sZ}} \leq 1$ & 4,571 & - & - & - & - & - \\
\hline 3. group & $1>\mathrm{v}_{\mathrm{SZ}} \leq 1,3$ & 2,512 & 2,059 & - & - & - & - \\
\hline 4. group & $1,3>\mathrm{v}_{\mathrm{sZ}} \leq 1,8$ & 1,351 & 3,219 & 1,161 & - & - & - \\
\hline 5. group & $1,8>\mathrm{v}_{\mathrm{sZ}} \leq 2,4$ & 3,650 & 0,920 & 1,138 & 2,299 & - & - \\
\hline 6. group & $\mathrm{v}_{\mathrm{sZ}}>2,4$ & 2,232 & 2,338 & 0,279 & 0,881 & 1,418 & - \\
\hline
\end{tabular}

$*=\mathrm{P}<5 \%, * *=\mathrm{P}<1 \%$

During the homogeneity tests of the group pairs the samples showed homogeneous results so at the statistical process we used the LSD test, results can be seen in Table 3 . We found the largest difference between 2.-1. Group pairs with $4,57 \%$ methane content. Between group pairs the analysis of variance showed significant difference only between group pairs $2 .-1$. $\mathrm{P}<5 \%$.

For all the gas wells we carried out a linear regressive examination taking both methane content changes and wind speed intervals into account (Figure 2.). The relationship between the methane content changes of a particular gas well and the wind speed intervals can be calculated by the following equation: $y=-$ $5,28369 x+56,452, R 2=0,1699$. The coefficient of correlation is $\mathrm{r}=0,48$ so the closeness of relationships shows moderate correlation between the change of the methane content in all gas wells and the changes of wind speed intervals at the refuse dump. On the basis of the linear regressive examination we can conclude that the changes of wind speed interval might decrease the methane content of the landfill gas.

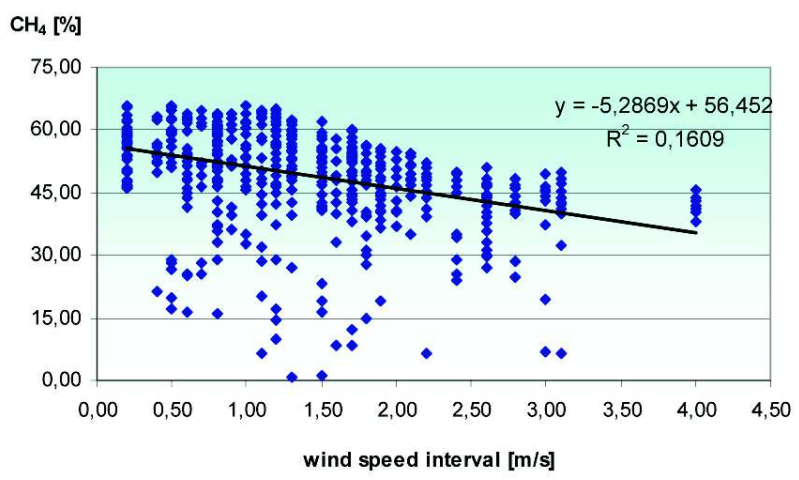

Figure 2. Changes of the methane content of landfill gas in different wind speed intervals $[7,10]$

During our examination we were looking for relationships between the characteristic methane content values of each gas well and the characteristic wind speed intervals at the refuse dump. So we combined all the 8 gas wells' methane content values and their belonging wind speed values. The results can be found in Table 4. From the results it can be seen that the least favorable value was found at the 5th gas well between 1.-6. wind speed interval group, 23,63-37,57\%, the value of average methane content was $32,53 \%$. The most favorable methane content value was found at the 6th gas well between geoups 1.-6. $(58,06-63,85 \%)$, the average methane content was $61,12 \%$.

During the statistical evaluation we found a relationship between the methane content values which characterize each gas well and the wind speed interval groups. The results can be seen in Table 5 . The homogeneity test was carried out by the Levene test and we used the LSD test in all the cases as the samples were homogeneous. We found significant differences, $\mathrm{P}<5 \%$, between 3.-1. group pairs at the $1^{\text {st }}$ gas well, between group pairs $2 .-1$. at the $3^{\text {rd }}$ gas well, between 6.-2. and 6.-5. group pairs at the $4^{\text {th }}$ gas well and between 3.-1. and 5.-1. group pairs at the $6^{\text {th }}$ gas well. At number 2,5,7,8, gas wells the analysis of variance did not show significant differences.

Table 4. Methane content values of each gas well with regard to wind speed groups

\begin{tabular}{|c|c|c|c|c|c|c|c|c|}
\hline $\begin{array}{c}\text { Wind } \\
\text { speed } \\
\text { group }\end{array}$ & $\begin{array}{c}\text { 1. } \\
\text { gas } \\
\text { well }\end{array}$ & $\begin{array}{c}\mathbf{2 .} \\
\text { gas } \\
\text { well }\end{array}$ & $\begin{array}{c}\mathbf{3 .} \\
\text { gas } \\
\text { well }\end{array}$ & $\begin{array}{c}\mathbf{4} . \\
\text { gas } \\
\text { well }\end{array}$ & $\begin{array}{c}\mathbf{5 .} \\
\text { gas } \\
\text { well }\end{array}$ & $\begin{array}{c}\mathbf{6 .} \\
\text { gas } \\
\text { well }\end{array}$ & $\begin{array}{c}\mathbf{7 .} \\
\text { gas } \\
\text { well }\end{array}$ & $\begin{array}{c}\mathbf{8 .} \\
\text { gas } \\
\text { well }\end{array}$ \\
\hline 1. group & 39,28 & 34,06 & 37,68 & 55,11 & 49,59 & 58,06 & 49,99 & 60,34 \\
\hline 2. group & 49,00 & 37,57 & 48,04 & 57,63 & 53,06 & 59,32 & 55,01 & 60,61 \\
\hline 3. group & 48,74 & 33,39 & 41,90 & 54,07 & 48,07 & 63,10 & 52,52 & 57,62 \\
\hline 4. group & 52,94 & 23,63 & 45,71 & 48,18 & 54,54 & 61,37 & 54,31 & 55,24 \\
\hline 5. group & 38,95 & 33,87 & 41,27 & 57,82 & 53,13 & 63,85 & 52,20 & 61,38 \\
\hline 6. group & 51,63 & 33,67 & 45,35 & 44,32 & 52,00 & 61,80 & 49,67 & 60,05 \\
\hline Total & 47,10 & 32,53 & 43,45 & 53,03 & 51,67 & 61,12 & 52,50 & 58,99 \\
\hline
\end{tabular}

Table 5. Results of the statistical processes of each gas well.

\begin{tabular}{|c|c|c|c|c|c|}
\hline & \multirow{2}{*}{$\begin{array}{c}\text { Results of } \\
\text { homogenity } \\
\text { examination }\end{array}$} & \multirow{2}{*}{$\begin{array}{c}\text { Significant } \\
\text { differences } \\
\text { between } \\
\text { group } \\
\text { pairs } \\
\text { in } * \mathrm{P}<5 \% \\
\text { level }\end{array}$} & \multirow{2}{*}{$\begin{array}{c}\text { Significant } \\
\text { differences } \\
\text { between } \\
\text { group } \\
\text { pairs } \\
\text { in } * * \mathrm{P}<1 \% \\
\text { level }\end{array}$} & \multicolumn{2}{|c|}{$\begin{array}{c}\text { Methane content } \\
\text { differences } \mathrm{CH}_{4} \\
{[\%]}\end{array}$} \\
\hline & & & & $* \mathrm{P}<5 \%$ & $\begin{array}{c}* * \\
\mathrm{P}<1 \%\end{array}$ \\
\hline 1. gas & homogeneous & $3 .-1$. & - & $13,66 \%$ & - \\
\hline 2. gas & homogeneous & ns & ns & - & - \\
\hline 3. gas & homogeneous & $2 .-1$. & - & $10,36 \%$ & - \\
\hline 4. gas & $\begin{array}{l}\text { homogeneous } \\
\text { (LSD) }\end{array}$ & $\begin{array}{l}6 .-2 . \\
6 .-5 .\end{array}$ & - & $\begin{array}{l}13,31 \% \\
13,49 \%\end{array}$ & \\
\hline 5. gas & homogeneous & ns & ns & - & - \\
\hline 6. gas & $\begin{array}{l}\text { homogeneous } \\
\text { (LSD) }\end{array}$ & $\begin{array}{l}3 .-1 . \\
5 .-1\end{array}$ & - & $\begin{array}{l}5,03 \% \\
5,78 \%\end{array}$ & - \\
\hline 7. gas & homogeneous & $\mathrm{ns}$ & ns & - & - \\
\hline 8. gas & homogeneous & ns & ns & - & - \\
\hline
\end{tabular}

For all the gas wells we carried out a linear regressive examination taking both methane content values and wind speed values belonging to wind speed intervals into account. The relationship between the methane content changes of a particular gas well and the wind speed intervals can be calculated by the following equation (Table 6). From the processed data we can see that the effect of the wind speed interval changes on methane content in the cases of gas wells 4,5,7 correlation coefficient changed between $r=0,57-0,66$, the closeness of relationship shows moderate correlation. In the cases of gas wells 1,2,3 there are loose correlation relationships and correlation coefficient is between $r=0,12-0,33$. In the cases of gas wells 6 and 8 there is tight correlation and correlation coefficient is $r=0,74-0,76$. On the whole we can say that the changes of wind speed intervals in a particular area influences the methane content of the produced landfill gas since the airflow on the side of the landfill causes vacuum on the top of the dump and pulls the valuable methane out of the waste dump so methane content can decrease.

Table 6 . Coefficient of correlation changes by gas wells with regard to methane content and wind speed intervals

\begin{tabular}{|c|c|c|c|}
\hline & Linear equation & $\mathbf{R}^{\mathbf{2}}$ & $\mathbf{r}$ \\
\hline 1. gas well & $\mathrm{y}=-1,5841 \mathrm{x}+48,555$ & 0,0152 & 0,1232 \\
\hline 2. gas well & $\mathrm{y}=-5,3454 \mathrm{x}+43,672$ & 0,0643 & 0,2535 \\
\hline 3. gas well & $\mathrm{y}=-3,3061 \mathrm{x}+50,314$ & 0,1117 & 0,3342 \\
\hline 4. gas well & $\mathrm{y}=-7,9509 \mathrm{x}+63,502$ & 0,4232 & 0,6505 \\
\hline 5. gas well & $\mathrm{y}=-4,642 \mathrm{x}+57,368$ & 0,3338 & 0,5777 \\
\hline 6. gas well & $\mathrm{y}=-6,1143 \mathrm{x}+64,857$ & 0,5621 & 0,7497 \\
\hline 7. gas well & $\mathrm{y}=-5,7277 \mathrm{x}+60,316$ & 0,4445 & 0,6667 \\
\hline 8. gas well & $\mathrm{y}=-6,8312 \mathrm{x}+64,912$ & 0,5902 & 0,7682 \\
\hline
\end{tabular}




\section{Discussion}

We diagnosed how the different wind speed intervals at the refuse dump influence the methane content of landfill gas where coefficient of correlation is $r=0,48$. Between the variables there is negative correlation which means that when wind speed values increase methane content values decrease. This process can increase during the raising of the landfill site when the height of the $3 \mathrm{~m}$ wide and $2 \mathrm{~m}$ high ramparts on the outside edge of the prisms gets higher than the height of the waste in the refuse dump. By that the methane content of the recovered landfill gas can decrease and have higher oxygen content. After linear regression examination (Table 6) we found a moderate negative correlation in the cases of 4, 5, 6, 7 and 8 gas wells. In the cases of the other gas wells we found loose negative correlations. All things considered we can state that the wind speed intervals at the refuse dump influence the methane content of landfill gas.

\section{Conclusion}

Based on the statistical processes with regard to wind speed interval tests we concluded that the wind speed changes specific for the landfill site affect the methane content of the landfill gas. Relationships between wind speed changes and methane content can be described by the equation: $y=-5,2869 x+56,452$, $\mathrm{R}^{2}=0,1699$. Between the variables there is negative correlation, if wind speed increases the methane content values decrease. Closeness of relationships between wind speed changes and methane content are moderate. Our proposals are the following: with the increase of wind speed the elements of the extraction system have to be coordinated in a way that the volume of the vacuum has to be increased until it levels off with the volume of the vacuum on top of the waste. Operators should take into account the volume of extraction and environmental parameters such as average temperature, precipitation intensity and wind speed in order to be able to plan the most favourable recovery of landfill gas and methane content.

The methane content of the landfill gas is influenced by the characteristic of wind speed intervals and the changes of wind direction. Our proposals are the following: at the surrounding areas at gas wells leachate must be returned in the waste and moisture content level must remain the same and within the range of gas wells covering and closing must be done in order not to let landfill gas into the air. With the increase of wind speed the elements of the extraction system have to be coordinated in a way that the volume of the vacuum has to be increased until it levels off with the volume of the vacuum on top of the waste. In the cases of gas wells we suggest a transition to a telemetry system with continuous control instead of a periodical regulation of valves.

It means that all the parameters about the quality of landfill gas, which are provided by the gas measuring points at the gas wells are stored on a computer.

The telemetry system would monitor the data sent by the meteorological station and the volume of extraction at the gas wells could be determined on the basis of that. With the usage of it the most favourable quality and quantity parameters can be guaranteed. Overall, we can say that the characteristic wind-speed intervals of the landfill affect the methane content of the landfill gas; due to the location of the gas wells the air coming upward on the waste dump results in a vacuum on top of the waste body, and almost pulls out the valuable landfill gas from the waste body, thus the methane content value will decrease, which causes operational problems.

\section{References}

[1.] Nagy V., Farkas F.: 2012. Exhaust gas tests using of biofuels in IC engines, Hungarian Agricultural Engineering, 24/2012, pp. 49-52, ISSN: 0864-7410

[2.] Sembery P., Tóth L.: 2004. Hagyományos és megújuló energiák, Szaktudás Kiadó, Budapest, p. 274-279

[3.] Hódi J.: 2009. Depóniagáz kutak problémái, megoldási lehetőségek XIX. Nemzetközi Köztisztasági Szakmai Fórum, Szombathely, 2009. április 21-23

[4.] Sallai L.: 2009. Cofermentation of organic waste of the pilot farm of SZTE MGK, Hungarian Agricultural Engineering N0 22/2009, HU ISSN 0864-7410

[5.] Tóth L. et al.: 2012. Alternatív energiaellátási rendszerek az agrárgazdaságban, Magyar Agrárkamara, Szaktudás Kiadó Ház, Budapest, ISBN 978-615-5224-22-5, 235.p 188-194pp. 208$215 \mathrm{pp}$

[6.] Woperáné S. Á., Tanka S.: 2011. Hulladéklerakóban keletkező biogáz hasznosítása, Miskolci Egyetem, Tüzeléstani és Hőenergia Intézeti Tanszék, Anyagmérnöki Tudományok, Miskolc, 36/1. kötet. pp. 79-90

[7.] Molnár T.: 2007. Quantitative and qualitive analysis of the biogas production from the municipal solid waste, Hungarian Agricultural Engineering N0 20/2007, pp. 20-22, HU ISSN 08647410

[8.] Molnár T.: 2009. The impact of the weather conditions for the parameter of the production of landfillgas, Hungarian Agricultural Engineering N0 22/2009, pp. 91-94, HU ISSN 08647410

[9.] Molnár T.: 2012. Landfill gas quality and quantity parameter changes depending on precipitation intensity, Mechanical Engineering Letters, HU ISSN 20603789

[10.] Molnár T.: 2008. Landfillgas composition analysis, 50.th JubileeGeorgikon Scientific Conference, Keszthely 2008. szeptember 25-26, p. 165, ISBN 978-963-9639-31-7.

[11.] Loll U.: 2001. Biogaspotenziale im Klärschlamm und anderen biogenen Abfällen, KA Wasserwirtschaft, Abwasser, Abfall, 48. k. 10. sz. 2001. p. 1424-1429.

[12.] Stachowitz W. H.: 2004. „Berechnung“ oder Abschätzungen von Gasproduktionsmengen Gasprognose

[13.] Tabasaran O.: 1981. Gas production from landfill. In: Bridgewater AV, Lidgren K, editors. Household waste management in Europe, economics and techniques. New York: Van Nostrand Reinhold Co.; 1981. p. 159-175.

[14.] Sváb J.: 1981. Biometriai módszerek a kutatásban, Mezőgazdasági Kiadó, ISBN 9632310136, p.50-51., Budapest

[15.] Bai A.: 2007. A biogáz. Szakkönyv. Társszerzők: Bagi Z., Bartha I., Fenyvesi L., Hódi J., Kovács K., Mátyás L., Mogyorósi P., Petis M. Száz Magyar Falu Könyvesháza Kht . ISBN 978963 702430 6. Budapest, 2007. pp. 1-284

[16.] Bai A.: 2015. Helyi közlekedés és hulladékgazdálkodás. Magyar Energetika 22 (1) pp. 21-25 (2015)

[17.] Christensen, T. H. H., Kjeldsen P.: 1989. Basic biochemical process in landfills Sanitary Landfilling (ed.: CHRISTENSEN, TH.H.-COSSU, R.-STEGMANN, R.) Academic Press, pp. 29-48.) [18.] Stachowitz W. H.: 2005. Grundlagen der Fassung und Entsorgung von Deponiegas, DAS - IB GmbH Stand: Juli 2005. [19.] Stief K.: 1985. Anforderungen an die Wirksamkeit von Deponiebasisabdichtungen Deponiebasisabdichtung mit Kunstoffdichtungsbahnen, Beihefte zu Müll und Abfall, H.22. pp. 9-13. 